\title{
Organizational hybridity and mission drift in innovation partnerships
}

Vikkelsø, Signe ; Stokholm Skaarup, Mikkel ; Sommerlund, Julie

\section{Published in:}

European Journal of Innovation Managament

DOI:

10.1108/EJIM-09-2020-0384

\section{Publication date:}

2022

\section{Document Version}

Peer reviewed version

Citation for published version (APA):

Vikkelsø, S., Stokholm Skaarup, M., \& Sommerlund, J. (2022). Organizational hybridity and mission drift in innovation partnerships. European Journal of Innovation Managament, 25(5), 1348-1367.

https://doi.org/10.1108/EJIM-09-2020-0384

\section{General rights}

Copyright and moral rights for the publications made accessible in the public portal are retained by the authors and/or other copyright owners and it is a condition of accessing publications that users recognise and abide by the legal requirements associated with these rights.

- Users may download and print one copy of any publication from the public portal for the purpose of private study or research.

- You may not further distribute the material or use it for any profit-making activity or commercial gain.

- You may freely distribute the URL identifying the publication in the public portal.

Take down policy

If you believe that this document breaches copyright please contact rucforsk@kb.dk providing details, and we will remove access to the work immediately and investigate your claim. 


\section{eEmerald $\begin{aligned} & \text { European Journal of } \\ & \text { Innovation Management }\end{aligned}$}

\section{Organizational Hybridity and Mission Drift in Innovation Partnerships}

\begin{tabular}{|r|l|}
\hline Journal: & European Journal of Innovation Management \\
\hline Manuscript ID & EJIM-09-2020-0384.R2 \\
\hline Manuscript Type: & Original Article \\
\hline Keywords: & $\begin{array}{l}\text { Partnership, Innovation, Organizational theory, Management, Project } \\
\text { evaluation, Organizational effectiveness }\end{array}$ \\
\hline \multicolumn{2}{|l}{} \\
\hline
\end{tabular}




\section{Organizational hybridity and mission drift in innovation partnerships}

\section{Introduction}

Innovation partnerships are a popular choice to support the transformation of knowledge into societal growth and development. Particularly, European Union countries have increased public funding for innovation projects that are collaborations among universities, industries, and other actors. It is expected that pooling resources, combining expertise, and distributing risk will transform research knowledge into commercially viable products (Bendis and Byler, 2009; European Commission, 2010). However, despite considerable effort it has been difficult to evaluate the outcome of innovation partnerships (Arnold, 2000) because it is not easily captured except through 'proxies' (Jaffe, 1998; Langford et al., 2006) and may depend strongly on partnership constellation. For instance, one study confirms a positive correlation between peer-reviewed publications and innovation partnerships but only for small and medium-sized enterprises in larger projects, and between granted patents and partnerships but only for young firms in larger projects (Chai and Shih, 2016). Another study reports a positive correlation between valuable patents in companies partnering with a basic research institution (Cassiman et al., 2018). Positive effects have also been observed for patent counts and employment growth, but only for already innovative firms (Kaiser and Kuhn, 2012).

Innovation partnerships tend to be hybrid in nature, often encompassing partners across disciplines and sectors with different interests, and they have a high failure rate (Lokshin et al., 2011). They may struggle with challenges such as trust, coordination, and motivation (Breznitz and Zehavi, 2010) as well as issues pertaining to learning and commitment (Bammer, 2008). Some partnerships become caught in vicious circles of decision-making, where efforts to solve one problem aggravate other problems, altering the trajectory of the innovation partnership (Ungureanu, 2018b). Several scholars have expressed the requirement for a better understanding of the risk of 'mission drift' and the dynamics through which hybrid organizations, such as innovation partnerships, function over time in order to appreciate how they progress towards their goals and how internal and external conditions affect this progression (Ebrahim, 2014; Battilana et al., 2017; Ungureanu et al., 2018a).

In this study, we focus on the dynamics of hybrid partnerships and the handling of the related risk of mission drift. We analyze the organizational challenges of innovation partnerships funded by Innovation Fund Denmark (IFD). IFD works well as an example because it resembles public funding schemes in other countries and is relatively accessible for data collection. To obtain IFD funding, partnerships must present co-investment and innovation projects comprising R\&D targets, business cases, and societal objectives such as job creation or sustainability. The aims and criteria of IFD represent global trends, emphasizing strong market orientation, composite innovation goals, and diverse partner mix.

Through eight broad and one deep case study, we explore the mission challenges IFD partnerships face and how they attempt to solve them. We find that the partnerships appreciate the support of IFD, but struggle to reconcile different interests and temporal structures. Elaborating one particular case, we describe how the partnership manages to build mutual trust and coordinate across diverse participants and time horizons. However, its multiple goals also become a growing problem, and some goals are eventually downplayed to the frustration of partners. We theorize that a tension exists between partnership complexity and degree of formalization: the more partners and interests a partnership comprises, the narrower or more open goals must be defined for it to succeed in meeting these. If partnership composition and formalization are not well designed for its purpose, the partnership is vulnerable to mission drift, honoring some goals, abandoning others, or displacing goals 
altogether. This is an important lesson for funding programs such as the IFD, which simultaneously encourages multiple partners and composite goals in combination with a short timeframe and little formalization. It is also a contribution to the innovation partnership literature, which is still in search of balanced and appropriate governance mechanisms, including evaluation tools. We conclude the paper by discussing these implications.

\section{Literature review}

While there is no comprehensive understanding of how mission drift develops in innovation partnerships, or the means to mitigate it, there exist important theoretical elements across the traditions of transaction cost economics, strategic management theory, and organization theory. They emphasize the challenges of organizational partnerships relating to trust, goal setting, learning, and coordination, which we present in the following. We conclude that the combined literature is strongly relevant to a multifaceted understanding of mission drift, but more research is required to specify the precise dynamics in different types of partnerships and to arrive at clear propositions on appropriate governance mechanisms.

\subsection{Trust and formal contracting}

From a transaction cost perspective, it may be economically or operationally advantageoustypically reducing costs or sharing risks - to form a partnership, for example, when engaging in high-risk projects that require substantial information sharing and organizational flexibility. However, studies point to the difficulty of assessing the benefits and risks of collaboration and building trust among partners (Ring and Van de Ven, 1994; Nooteboom, 1996, 1999; Woolthuis et al., 2005). Nooteboom distinguishes between two types of trust: competence and intentional. The first refers to trust in a partner's competences, such as technical, managerial, and cognitive. The second refers to trust in the sincerity of the partner's intentions and willingness to refrain from opportunism (Nooteboom, 2002). Both types of trust are necessary to further a 'free flow of information and simultaneously limit opportunistic behavior' (Häusler et al. 1992, p.48). This makes communication and information transfer more effective and facilitates a higher frequency of interactions (Chen and Wang, 2008; Collins and Smith, 2006). Cooperation in a partnership is possible without trust, but 'trust not only makes cooperation more probable and less expensive; it could also deepen and expand it'. (Breznitz and Zehavi, 2010, p.303). In contrast, a lack of trust diminishes the sharing of knowledge and skills and impedes joint investments (Coleman, 1988).

Das and Teng (1996) point to trust and control as two distinct sources of partner confidence. Entering a mutual contract defining the goals, rights, and responsibilities of the partnership can reduce the uncertainty and conflicts of collaboration (Vedel, 2020), but Woolthuis et al. (2005) identify conflicting views on the relationship between trust and contracts in partnerships. While transaction cost economics and contract theory perceive a contract as the 'basis for trust since it limits the opportunities and incentives for opportunism', other scholars argue that contracts are negatively related to trust because '(c)ontracts can be detrimental to trust development since contracts can be interpreted as a sign of distrust' (ibid, p.818) and because trust precedes and embeds the relationship in such a way that it decreases the requirement for formal contracts. Trust signals positive expectations regarding the competence or goodwill of other actors in a partnership (Das and Teng 2001; Ebers and Maurer 2014). Indeed, relationships characterized by trust have been found to be more successful (Woolthuis et al., 2005, p.834). Trust can be built through frequent interactions and exchanges among partners (Lawler and Yoon, 1998; Kollock, 1994), which help establish psychological contracts and may substitute for formal contracts (Ring and Van de Ven, 1994). Contracts and trust are not mutually exclusive but may 
complement each other, although reducing risk and establishing trust can be costly and limit institutional flexibility as well as the ability to innovate (Zucker, 1986).

Breznitz and Zehavi argue that the challenges of risk and trust are accentuated in innovation partnerships because innovation in technology-intensive industries often involves the competitive advantage of the firm, which enhances the potential for distrust owing to the high costs of knowledge leakage (2010, p. 304). Uncertainty in research processes may further increase the risk of participation (Häusler et al. 1992, p.48). Patents and other intellectual property protection mechanisms (IPPM) are emphasized as critically important in ensuring the formation of innovation partnerships and sharing of key information in order to successfully complete the designed research, but Hertzfeld and colleagues encourage more studies on the interplay between such mechanisms. Their study finds that early-stage agreements may be more effective than patents, and that IPPMs are more easily signed when partners know each other from prior experience. In general, Intellectual Property Rights (IPR) negotiations are more complex between firms and universities as well as between firms in the same industry (ibid, p.837). Trust can substitute contractual control mechanisms to some extent (Schøtt and Jensen, 2016, p.1236). This allows a more flexible and rapid innovation process and increases the intensity and quality of exchanges across firms (Molina-Morales et al., 2011).

\subsection{Learning and coordination}

While contracts and other formal agreements reduce the risk of collaborating, they may also diminish the window for learning and improvisation (Woolthuis et al., 2005; Schøtt and Jensen, 2016) and skew the balance towards 'exploitation' of certainties rather than 'exploration' of possibilities (March, 1991). Ideally, partnerships are ambidextrous (Benner and Tushman, 2003) and are capable of both exploitation and exploration. This includes the ability to shift freely among 'process management activities', that is, efforts to map, improve, and adhere to organizational processes, and to break with these depending on the type of innovation (incremental or radical) and on the circumstances (stable or turbulent) (ibid, p.252).

Bammer elaborates on the learning challenges of R\&D partnerships as follows. First, they must effectively harness internal differences and compile the necessary knowledge, skill, and perspectives 'to bear on the issue of interest' but also handle differences - in worldviews, motivations and modi operandi - that lead to unproductive conflicts (Bammer, 2008, p.877). Second, they must ensure that the scope and goal of the project are ambitious and fulfil expectations but also be realistic in terms of available resources and knowledge. Finally, as funding for partnerships is often obtained from multiple sources with each constraint on recipients, it is a challenge for project managers to balance the conflicting requirements and requested outcomes whilst preserving a space for creativity and autonomy (ibid, p.885). The balancing acts among trust-building, coordination, and learning in R\&D partnerships is described by Larsson and colleagues as a dilemma:

The interorganizational learning dilemma is that (1) being a good partner invites exploitation by partners attempting to maximize their individual appropriation of the joint learning, and (2) such opportunistic learning strategies undercut the collective knowledge development in the strategic alliance (Larsson et al., 1998, p.255).

How this dilemma is transgressed depends on the partners' ability to learn from their participation. Kumar and Nti argue that the 'absorptive capacities' of each partner determine if the alliance reaches a desirable interorganizational equilibrium: 
Unfavorable outcome discrepancies relate to the inability of the partners to create satisfactory economic value or learn from the alliance; unfavorable process discrepancies occur when some partners are dissatisfied with the pattern of interaction, adversely affecting their ability to sustain positive feelings of psychological attachment to the alliance relationship (Kumar and Nti, 1998, p.356).

Navigating the challenges may be more difficult when participants are inexperienced and innovation goals are unfocused. Lokshin and colleagues find that firms with a productfocused innovation strategy are more likely to survive the 'bumpy road' of partnerships than firms pursuing a cost innovation strategy (e.g., making production processes more cost effective) because a product focus enables a more precise goal setting and partner identification (Lokshin et al., 2011). Gilier et al. (2012) emphasize that creating a common purpose is typically difficult and requires a focused process of matching and building partners' concepts and knowledge spaces.

\subsection{Hybridity and goal setting}

Because of their complexity and inner tensions, innovation partnerships are described as 'hybrid partnerships' (Ungureanu et al., 2018b) or 'hybrid spaces' (Perkman et al., 2018). The term hybridity refers to organizational arrangements that encompass multiple success criteria, values, governance principles, and institutional logics such as commercial, academic, sustainability, and welfare logics (Voltan and De Fuentes, 2016; Quelin et al., 2017; Caldwell et al., 2017). Their composite nature enables them to juggle conflicting demands but also increases the internal coordination problems arising from competing identification targets and internal conflicts (Battilana et al., 2017). In publicly funded innovation partnerships, the hybridity may be further increased by a 'public financer-private producer split' (Breznitz and Zehavi, 2010, p.302): the public funder aiming to maximize the spillover effect from the collaboration to the local economy, while the private actors seeking to maximize their own utility. For partnerships across the university-industry divide, the complexity of goals further increases with the university's purpose of research. Breznitz and Zehavi note that a lack of trust in situations where private firms cooperate is likely to push partners to restrict the scope of collaboration. However, they regret that it is still largely undescribed how hybrid partnerships mediate between shared purpose and divergent raison d'êtres (Breznitz and Zehavi, 2010).

A partnership's efforts to estimate risks, build trust, coordinate interests, and ensure learning may come to interact in counterproductive ways in which the solution of one challenge increases other challenges; this vicious circle traps some hybrid partnerships and alters their trajectory (Ungureanu et al., 2018b). Ungureanu et al. identify three dysfunctional processes that may complicate the recalibration of a stuck partnership. The first is 'escalation of commitment', which refers to the tendency in social relations to keep extending the collaboration despite signs of failure. The second is 'procrastination', that is, delaying difficult decisions or actions because of difficulties in agreeing or presenting the required resources, and finally, 'indecision', which covers a 'chronic ambivalence' regarding high conflict decisions or uncertainty regarding time horizons and resources (Ungureanu et al., 2019 , p.1341). However, it has been reported from studies of other hybrid organizations that tensions and deadlocks can start processes in which intended hybridity is reduced and the 'mission' set in drift (Battilana et al., 2017). The risk of such mission drift is well documented in studies of social enterprises, but more research is warranted: '(L)ittle is known about how mission drift occurs, how it impacts organizations, and how organizations should respond' (Grimes et al., 2019, p.819). This will allow the development of distinct governance mechanisms 'for avoiding mission drift and for ensuring that hybridity can be sustained' 
(Ebrahim et al., 2014, p.83).

\subsection{Seeking the appropriate organizational design}

The call for governance mechanisms to handle mission drift is understandable in light of the literature's extensive coverage of challenges related to trust, coordination, and learning, and how partnerships can lose sight of shared goals in this complexity. At the same time, a fixed set of tools is unlikely to be relevant across all cases. What are the crucial dimensions that may determine a concrete solution? Here, the literature still seems scattered across a multiplicity of aspects such as the type of innovation in question, type of partners, their absorptive capacities, type of funding, level of uncertainty and so forth. While the notion of organizational hybridity encapsulates these multiple and interrelated dimensions, it does not offer specific guidance. A possible road forward may be to adopt the proposition from contingency theory that there is no best way of organizing, but that it depends on situational factors, that is, the internal and external environment of the organization (Lawrence and Lorsch, 1967). This paper intends to open such an inquiry by investigating more closely the organizational environments of innovation partnerships related to mission drift and how these may determine the right organizational design and governance mechanisms.

\section{Method}

To investigate the dynamics of mission drift in innovation partnerships and appropriate governance mechanisms, we designed a qualitative empirical research project comprising eight pilot studies of IFD partnerships and one deeper case study. This methodological approach allows us to test existing theories on the organizational challenges of innovation partnerships as well as generate new empirical knowledge by exploring partnerships in their contexts (Yin, 2003; Flyvbjerg, 2006).

The studied partnerships are all established through the IFD funding scheme called Grand Solutions, which requires applicants to partner up across universities, industries, and other actors in larger collaborations. The program has a broad focus, covering both strategic research and research-based innovation. In addition to challenge-driven projects, Grand Solutions also invests in 'opportunity-driven' research and innovation in new areas. The budget for Grand Solutions varies each year but is typically between $€ 95$ and $€ 105$ million. The fund invests $€ 0.7-4$ million per project, but a number of investments are considerably larger. Grand Solutions investments typically run over three to five years and are expected to achieve effects within a period of two to ten years after completion. ${ }^{1}$

The nine innovation partnership cases were selected based on regional and sectorial representation (see Table 1) as well as the different sizes of partnerships. Interviews were conducted with the principal investigators of the nine partnerships and with two investment managers from IFD who were responsible for overseeing grants given by the Innovation Fund. The interviews were conducted in 2017 and focused on partnership formation, establishment of goals, and organizational challenges and solutions under the IFD framework. The interview guide was constructed with the dual purpose of investigating the general themes from the literature, namely, trust, goal setting, learning, and coordination, as well as exploring the particular dynamics related to the missions of the partnerships in question. Interviews were transcribed and analyzed through semantic coding with regard to the aforementioned themes. We identified additional themes relevant to understanding the risk of mission drift and possible solutions. Among these emerging themes were 'partnership complexity' and 'degree of formalization', which seemed to co-vary across the nine cases.

\section{[INSERT TABLE I HERE]}

\footnotetext{
${ }^{1}$ See Innovationsfondens Årsrapport (2018).
} 
One partnership, here called 'EO', was chosen for an in-depth case study. This selection was made based on its openness to empirical data collection, its success in continuing the partnership to a second phase, and its high partner complexity. The second phase of the EO partnership is described in the IFD catalogue by the following statement:

Two years ago, Innovation Fund Denmark teamed up with some of the country's big companies, universities and Region X in an ambitious, four-year collaboration called EO. The goal was to promote the Danish production of biotech and create new companies. Halfway through the project, the shared investment has created nine new companies with forty high-technology jobs (IFD homepage, our anonymization).

EO consists of multiple partners: five companies, two universities, one investment firm, and nine start-up companies. It focuses on process innovation in companies, that is, optimization of core production processes through the development of automated process monitoring devices. The participating companies opened up their production lines for scrutiny. This distinguishes EO from many other innovation partnerships, typically involving only the R\&D departments of companies and shielding off internal business processes. Nevertheless, we consider EO a paradigmatic case (Flyvbjerg, 2006), which represents the core features of an innovation partnership with high partnership complexity. This is a good example of a hybrid arrangement and possible mission drift.

The study of EO was conducted during the last months of 2017, and data were collected through document studies, participant observation, and interviews with 15 persons representing key actors in the partnership. The interviews focused on exploring the particular dynamics at play regarding the mission of the partnership, situations of mission crisis or conflict, and what the participants considered relevant solutions in such situations. The interview guide included questions pertaining to trust, goal setting, learning, and coordination in the partnership. It included questions on the role of partnership complexity (e.g., did the partnership have too many or too few partners?) and the degree of formalization (e.g., what had been formalized or kept informal?) pertaining to how the partnership handled four challenges. The interviews lasted between 45 and 115 minutes and were all transcribed. The transcripts were first coded in terms of general themes (trust, goal setting, learning, and coordination). Each theme was further coded based on the two emergent themes: partnership complexity and degree of formalization. Table 2 shows the general outline of our data display to illustrate how the interviews were coded. The coded interviews laid the foundation for our EO case analysis and for identifying core tensions among partnership complexity, goal diversity, and formal contracting.

\section{[INSERT TABLE II HERE]}

After coding and analyzing the EO data, we presented the preliminary findings, including a growing dissatisfaction among start-ups which we had identified in our interviews, to the board of the EO. This occasioned a longer discussion, and we agreed to subsequently conduct an anonymous survey among the ten board members (of which eight answered) regarding the following themes: partnership composition, access to sufficient scientific and technical capabilities, time horizon of the partnership, core goals of the partnership, and possibilities to expand the partnership. The survey showed some disagreement among partners, in particular, on whether the time horizon of EU was appropriate, if EO should move beyond solving basic process problems, and if EO should include companies beyond the region. It thus confirmed the tensions that we had identified through the interviews.

In total, the EO case worked to supplement the eight pilot studies with in-depth data on the dynamics of mission-drift and appropriate governance mechanisms. In the following, we will show how our findings confirm existing theories on the organizational challenges of 
partnership and the risk of mission drift but also add to these with new insights.

\section{Findings}

In the following, we present our findings across the nine partnerships regarding organizational challenges under the IFD framework. We especially highlight the particular dynamics of mission drift in the EO partnership. Both analyses highlight the tensions experienced regarding partnership complexity and the degree of formalization.

\subsection{General challenges of IFD partnerships}

Interviews with the principal investigators (PIs) of the nine Grand Solutions partnerships point to a number of benefits associated with IFD funding. The most important benefit is the possibility of attracting public funding to projects that would be too costly to work on for universities and industry alone. The PIs all describe the application process as rather straightforward and with good sparring from the IFD Scientific Officers to the degree that they were available. They also confirm the challenges of trust, goal setting, learning, and coordination, no matter how successful the partnerships otherwise are. The PIs present these challenges as fundamental to their daily work in partnership collaboration.

\subsubsection{Goal setting}

The PIs experience tensions associated with differences in partners' goals. For companies, the goal is ultimately economic return on investment either through new products and services or through a reduction in production costs. For research institutions, the essential goal is publishable knowledge and patents but also $\mathrm{PhD}$ students and postdocs as a way to foster academic talent. For the IFD, the goal is 'societal value for Denmark', which is practically defined as 'growth and employment', that is, new jobs created and start-ups. There is sometimes an added focus on sustainability, defined as a quantified estimation of reduced $\mathrm{CO}_{2}$ emissions, and other times as 'not only understood as monetary value but for instance quality of life, cleaner environment etc.'

When partners apply for funding with the Grand Solutions scheme, a business model for the project is obligatory. The business plan is supposed to work as a representation of the negotiated and aligned goals of partners. However, the business model must also comprise plans for creating growth and job creation within three to five years. For a company, a horizon of three to five years before the results begin to show is long and difficult. It is perceived as non-productive and challenging to the company's raison d'etre. In contrast, the same planning horizon is short in research, and research leaders find it difficult or unattractive to deliver finite results within that timeline. Working with shorter timelines can be hard to defend in the research community, as they contradict the raison d'etre of the research communities and universities. These differences point to a deeper tension in the time-to-goal and basic purpose of companies and universities, respectively. Most PIs agree that IFD's timeframe of three to five years is not realistic and that it disregards the work of alleviating tensions between the goals of companies and those of universities. Therefore, the business plans seldom work as the common goals and targets that IFD wants them to be, and goals in business plans are typically formulated in broad terms such as 'job creation' (with round numbers of estimated jobs created), 'improved competitiveness' and 'sustainability' (no exact measurements), 'network creation' (in broad terms), and ' $\mathrm{PhD} /$ postdoc education' (concrete numbers).

The PIs that run projects with new partners, rather than working in extensions of established collaborations, explain that they have found collaboration more difficult than expected, and that the way project goals were formulated in the partnership contracts did not guarantee sufficient alignment of expectations. This was particularly difficult in relation to 
international partners and peripheral horizontal partners, that is, partners that only contributed a minor element to the project. Often, the bulk of IFD funding is spent hiring junior researchers: $\mathrm{PhDs}^{2}$ or postdocs. Junior researchers are at the outset of their careers, and what they do during their years as junior researchers can be formative to their careers. When working in innovation partnerships, junior researchers find themselves squeezed between the interests of companies and research institutions. If they honor one set of interests over the other, they run the risk of disqualifying themselves for future careers within the other sector. Even if innovation partnerships are seen as a way of furthering sector mobility, PIs and junior researchers find career development challenging.

\subsubsection{Coordination}

When a partnership has successfully attracted funds, it is difficult for the PI to change its partners. PIs experience this as a challenge, as the innovation process may lead to a requirement for new partners and reduce the relevance of others. Even if the basic idea of partnerships is to further the exchange of knowledge between private companies and public research institutions, the actual dynamic can be experienced as stifling.

The PIs also mention that IFD itself, its staff, and success criteria are somewhat distant and difficult to understand. This critique is also put forward in the international evaluation of the Innovation Fund, which emphasizes the requirement for scientific officers with a better understanding of and competencies relevant to particular partnership projects (Ministry of Higher Education and Science, 2019, p.41). The evaluation report also describes the formalization of contracts, contract negotiations, and budget templates to be too complicated and time-consuming (ibid, p.46).

\subsubsection{Learning}

Our interviewees emphasize that companies and research institutions have different core purposes. Companies are interested in finding concrete solutions to discrete problems, whereas researchers are interested in detecting new problems and avenues of thinking. The mismatch might be summarized as a preference for exploitation of existing knowledge on one side, and exploration of new knowledge on the other. These two basic interests and perceptions regarding learning in partnerships are also related to the difference in the raison d'être mentioned above. Companies are not interested in negative results and often do not consider negative results to be results at all, but simply wasted resources. To researchers, a negative result can be just as valuable as a positive result and something that can be published. However, some companies also mention that collaborating with universities is important to meet in-house researchers' wishes for working with academic peers and continuing an academic style of learning.

\subsubsection{Trust}

Many of the IFD innovation partnerships are continuations of earlier collaborations, where partners continue matching existing know-how for the development of new products or services. Trustful relations are often very valued in collaborative relations, as they ensure smooth and informal coordination. However, that collaborations are oftentimes continuations of other relations in some form also means that they are typically not a question of doing new and targeted research and innovation together but to make further use of existing opportunities. Underscoring this point, the recent evaluation of IFD finds that the Grand Solutions innovation partnerships have the characteristics of a series of one-to-one projects rather than feeding into or building broader societal innovations (Ministry of Higher

\footnotetext{
${ }^{2}$ In Denmark, PhD students are paid employees.
} 
Education and Science (2019). The evaluation points to the requirement for an interdisciplinary ecosystem, where collaboration is not only carried out and directed by partners but is co-directed by funders to target innovation towards societal focus areas, for instance, through joint calls and coordinated actions (ibid, p.37).

In the following, we will focus on one of the IFD partnerships: EO. The case study deepens the understanding of the nature of challenges posed by goal diversity, learning, trust, and coordination. It also highlights how mission drift becomes a way of handling challenges on a practical day-to-day level.

\subsection{The challenges of the EO Partnership}

The EO innovation partnership comprises several universities, five well-established companies, and an investment firm. Since the start of EO, nine start-ups have also become part of the project. At the outset, EO was funded by the region, the EU Regional Development Fund, and its partners. The project was extended two years later, with additional funding from the region and IFD. Bringing together university researchers from chemistry, computer science, and process engineering with $R \& D$ and production units from the companies, EO focuses on innovation of bio-based production processes through six technical work packages. A seventh work package aims to spin off the developed process monitoring tools to be marketed by separate start-up companies. This extra package distinguishes EO as a partnership that spans the entire innovation spectrum from applied research to commercialization. EO considers itself a success. By the end of 2018, EO company partners had developed and implemented a number of cutting-edge automatic samplers and analytical equipment, $13 \mathrm{PhD}$ students and 17 postdocs had been enrolled, about 40 papers published, and 7 of the 9 start-ups continued with a total of 40 high-tech jobs. There was no update regarding these numbers at the time this paper was submitted.

\subsubsection{Trust and goal setting}

Trust is a major theme in interviews with EO informants. At the outset, the people who later joined the EO board representing the partners were invited to a meeting by 'Roger', who would later become the project manager. Rogers knew all of them and knew that they were interested in process innovation.

Together with one of my good friends, I attended a very strange meeting in X Company. The project was presented as a sketch. We did not get a damn thing about it and went out of the door laughing [...]. Shortly after, there was another meeting at the Y Firm, and the director of X Company was there and John from Z Company, and my good friend, who was the production manager at the W Company. Then, we came up with some concepts about what we wanted to. (Stephen, university professor)

A brief framework for the partnership was developed, including a number of specific innovation projects that all partners were interested in. Ideas for possible start-ups emerged soon. After more meetings, a formal agreement was reached. It was not comprehensive but contained elements that briefly specified the focus of the partnership, the mutual investments, and how resources and results would be shared. Some of the partners met objections in their home organizations but kept their initial participation lowkey and did not upfront inform their legal departments and top management in all details. The agreement did not address all issues, such as intellectual property rights related to start-ups. However, the instigating partners did not consider this a fundamental hindrance but something to work out at a later point.

The core goal of the partnership — optimizing continuous production processes through automated monitoring devices - appealed to the partner companies. Although they shared 
central goals, they were not direct competitors. Had they been competitors, they most likely would have been unwilling to share the necessary information and open up their manufacturing sites to external scrutiny. It also helped that some of the companies were organizationally related and shared a past in the same corporate group.

The mix of partners was an evident quality of the EO partnership, whose competencies spanned multiple relevant areas such as biochemical engineering, mathematical modeling, computer science, project management, and business law. Thus, relevant scientific and practical expertise as well as multiple real-life testing grounds in the companies were secured. The board of EO was staffed with top executives from the big companies, professors from universities, and a representative of the investment company. This was significant in establishing a sense of importance and commitment, which again helped convince a smaller, but essential, company to participate. For the investment firm, it was a significant success to attract a company outside the close circle of friends. It proved that the closely knit and trusting partnership had a wider potential:

Because we have created this much closer relation, they [the outside company] have discovered that there was in fact some knowledge on the shelves that they didn't know was there, which can be used in the companies from day one. At the same time, we have developed the collaboration so that universities... also discover that here is a research apparatus available on a large scale that they can exploit. So, in this way, it has been a win-win situation for both parties, and that has broken the ice. (James, investment firm)

Like high-tech and software companies, continuous production companies are typically cautious not to expose critical internal processes to potential competitors or public regulators. Likewise, universities actively protect their knowledge via patents or intellectual property rights (IPR). The participants in EO explained that their relatively relaxed approach to IPR was unique and probably reflected 'Danish culture', characterized by informality and high levels of trust. They also emphasize the prevalence of an 'academic culture', valuing collegiality, curiosity, and pursuit of knowledge. Many members of EO had earlier been affiliated with universities or worked in company research units, so they were familiar with the academic culture. In addition, university partners were not adamant to securing IPR. IPR often complicates collaboration contracts, and most patents will never be commercially interesting. The trust created through social ties and basic formal agreements undergirded partnership collaboration in the first R\&D-oriented phases of the project. Thus, the partnership, despite the many different types of partners, was characterized by high levels of confidence and a low degree of formalization.

\subsubsection{Coordination}

A crucial element in the successful coordination of activities, while maintaining a low degree of formalization, was EO's project manager, Roger. He also instigated the first meetings and the development of EO. The participants all point to Roger's management style as key to creating a positive spiral of confidence, exploration, and progress. If a collaborative issue or disagreement arose, Roger would intervene and help out. He insisted on holding frequent meetings with board and subprojects alike and would often invite himself to come by a company or university for a quick status update. This enabled him to detect problems and connect the relevant people. The frequent visits also kept participants focused and served to generate ideas for additional projects.

The project manager] is willing to take the discussions into the universities and say, "oh, that works" or "that will not work". He can see if it can or cannot [work]. So, he is sitting in at nearly all of the project meetings to really [ask] "What is happening now?" [...] I think he is here 
weekly, talking to me, pushing a little bit, and pulling me. [...] He has access to everything, so he goes directly into the plant and talks with the operators. (Hubert, company)

A core goal of EO was to form relevant innovation projects around production companies' requirement for specific solutions. The partnership board would identify the requirements, and steering committees were established around each innovation project. One subproject, formed with engineers from one company, university professors, and $\mathrm{PhD}$ students, serves as an example of the organization of subprojects. Based on a close study of the company's production challenges, a sensor device was designed to float in tanks and perform continuous measurements of their batches. This would allow better adjustments of, for example, temperature and, thus, a much higher batch quality. Practically, it involved the technical construction of the device and a computer program to allow real-time analysis of data from the device. Regular meetings in the steering committee ensured steady progress of the project and provided relevant information and results to the partnership board and other subprojects. The same model was used for the other subprojects. In some cases, the solution would be further developed with a start-up company to move from custom-made solutions to a commercially viable tool to be sold outside the partnership. This way of organizing a palette of subprojects under a shared umbrella reduced the requirement for detailed agreements, making smaller teams collaborate on different focused solutions. The low degree of partnership formalization is a central point here.

\subsubsection{Learning has a limit}

As the partnership progressed, disagreement arose between start-ups and other partners. Company partners were only interested in the subprojects until they obtained the technical solutions for their production processes. They were not interested in exploring solutions beyond this point. Likewise, universities felt satisfied with their cohort of PhD students and were not eager to spend time maturing solutions for the market. One professor who was helping a start-up was met with suspicion from university management and urged to declare that he had taken up external employment. The start-ups felt abandoned, as they expected the company partners to be their first and biggest customers and university partners to help mature prototypes. It became clear that the multiple and broad goals implied in the IFD grant were both virtue and vice. While the goals of subprojects directed towards technical R\&D resulted in useful solutions and new PhDs, the goals of job creation and start-ups, in contrast, were not clear successes. These goals had been formulated to meet the IFD's and regional interests based on the assumption that the developed solutions would be ready for commercialization.

Some of the start-ups suggested to expand the circle of partner companies who could invest in and test the solutions and, thus, help mature them. However, the board did not agree, as the company partners were not interested in including companies they did not know well and trusted. Similarly, adding new competences and resources to further the exploitation of results became an issue. Some start-ups lacked tool-making competences and requested additional partners that could help build technical solutions in a robust and commercially viable way. In contrast, the project manager considered their frustration as a sign that these start-up teams had not been put together with the adequate competences.

Expanding the number and types of partners would most likely require a readjustment of EO's mission, making the maturation of the start-ups' solutions to broader markets the central goal of the partnership. However, the established companies did not trust the start-ups to be able to produce sufficiently scalable solutions. The partners also feared that including toolmakers in the partnership would create a lock-in for EO solutions; they would become dependent on certain technological standards, thereby reducing the innovation window. The 
investment partner interprets these hesitations as a sign that some of the goals and subprojects of the partnership were not sufficiently vital to the companies, at least not to top management.

I mean they [the five big companies] have been formulating what is our most pressing challenges. Is it nice to solve it, or is it needed to solve it? Let us put it this way-it remains to be seen. There is a difference between those who are operating in the production room and those who are formulating business models in the headquarters. So, what is seen as a critical issue in the factories, might not be seen as such in the headquarters... I think we need to make a link from the production people to the headquarters in order to create a safer path for the small start-ups. (James, investment firm)

Frustration worsened as start-ups worked on commercializing the solutions. Some of these were less mature than expected, and the start-ups asked company partners to help by investing more in prototypes and pre-ordering fully matured tools. The companies were reluctant to do so because they did not fully trust the start-ups as steady suppliers. Companies operate in markets with heavy legislation and quality controls, and they hesitate to contract with suppliers that cannot present a track record of complying with such rules.

[The big companies] are hysterical about the acceptance of solutions in the business [i.e., that solutions are state-of-the-art in the sector] and with the authorities. So, when you want to make a deal with BigSeriousCompany-you might be a start-up, you might be a very strong old company, they do not care- do they trust the solution? [...] If you do not have the muscle from day one, you are very likely to lose the deal. (Bianca, investment firm)

\subsubsection{Mission drift}

The start-ups' push for including new partners to help with the commercialization of solutions displayed the limits of the partnership's original mission. The established companies wanted solutions that worked for them specifically and the universities wanted academically publishable results; they did not want to expand the partnership and potentially undermine the high level of trust undergirding these goals. While keeping the allencompassing mission narrative, the partnerships drifted towards the companies' goals with the university partners gradually accepting that their primary benefit from being partners in EO would simply be to hire PhDs and postdocs. This acceptance did not solve the tensions between academic exploration, practical exploitation, and commercialization but displaced them and put them with the junior researchers. The university partners worried that working in EO would make further university careers difficult for junior researchers. They also felt that the partnership had already taken too much of their time without giving rise to significant, publishable scientific findings.

The EO case shows that in addition to the challenge of exploration-exploitation, which is basic to most company-university partnerships, exploitation in itself can present conflicting goals. The start-ups' proposal to include additional partners in EO to help the commercialization of results threatened the partner proximity and trustful collaboration on company-specific solutions; something that would only work alongside a simultaneous narrowing of goals. Exploration also turned out to be more complex than anticipated Some of the companies initially doubted whether they could make use of university knowledge. As the project progressed, it was rather the time frames of the $\mathrm{PhD}$ students that bothered them. They also became impatient with the researchers' inclination to explore side avenues. In parallel, the university partners had initially been skeptical about whether industry projects would be sufficiently scientifically interesting, and they found this concern to be well founded as the project progressed. Most subprojects were not considered scientifically 
advanced by the researchers. Although EO was in many ways a successful partnership, all partners had to adjust their expectations and consider the different goals and expectations they each operated under.

The companies think it is going too slow. The scientists find they have to move too fast... you know, so we have a lot of...clashes of interest in the structure. (James, investment firm)

\section{Discussion}

Our study of the nine IFD partnerships confirms the challenges described in the literature regarding trust, goal setting, learning, and coordination in innovation partnerships. It also attests that mission drift is a real risk in partnerships. Owing to its relatively flexible framework and low degree of formalization, the IFD framework makes it possible for partnerships to handle these challenges. However, flexibility and a low degree of formalization also appear to aggravate the challenges of goal setting and coordination, which may lead to mission drift. Even if project managers are free to mediate tensions and solve problems, the combination of multiple goals, high partnership complexity, and short time frames presents difficulties that cannot be easily solved through better formal contracting or daily management. This was reported by all the partnerships we interviewed and confirmed by the IFD evaluation report (Ministry of Higher Education and Science, 2019).

The analysis of the EO partnership provided a deeper understanding of why and how tensions may lead to goal displacement and mission drift. The multiple goals and planning horizons were mediated through trust, relaxed formal agreements, and proactive project managers. However, the lack of formalized goals and responsibilities, which initially enabled the unusual collaboration, became a frustration, as it became clear that not all goals could be met. Requests at this point to expand and formalize the collaboration were rejected by the majority of partners, who feared that such expansion and formalization would undermine the trustful culture.

\subsection{Theorizing mission drift in innovation partnerships}

Our findings from the analyses of IFD-funded partnerships suggest that mission drift is tied to a core tension, relevant to all innovation partnerships, between partner complexity and degree of formalization. While a hybrid innovation partnership with multiple goals can thrive if mutual trust allows a relaxed definition of rights and responsibilities, the lack of formalization also increases the likelihood of not meeting all goals. Simultaneously, efforts to clearly define formal goals and responsibilities are likely to stop further matchmaking unless innovation goals are either narrowed or kept sufficiently open and non-committal.

This is a central insight, which opens up a more precise theoretical understanding of the interrelations among goal setting, partnership composition, and the formal governance of innovation partnerships. Adopting the classic distinction between exploitation and exploration as two equally important kinds of learning, we suggest the following proposition: the more diverse and the larger the circle of partners, the bigger the pressure toward either formalization of goals and relations (reducing the likelihood of exploration), or towards vagueness or openness in goal setting (thereby diminishing the likelihood of exploitation). Given that partnerships can vary on both these dimensions - partnership complexity and degree of formalization - the proposition can be further elaborated in terms of four basic forms of partnerships, that is, those organized: 1) with low partnership complexity and low formalization; 2) with low partnership complexity and high formalization; 3) with high partnership complexity and high formalization, and finally; 4) with high partnership complexity and low formalization. Drawing upon the contingency principle in organization theory (Lawrence and Lorsch, 1967; Vikkelsø, 2015) that organizations must be fitted to their 
task at hand, we suggest that the four forms do not serve all innovation goals equally well. Each form is likely to drift toward a particular type of innovation:

- a close collaboration on incremental improvement,

- an open collaboration on radical innovation,

- a matching platform for technology or knowledge transfer, and

- a network for non-committal serendipity.

These points, which are illustrated in Table 3 below, are also the main contributions of this study.

\section{[INSERT TABLE III HERE]}

The case of EO would be an example of a partnership located uncomfortably between the two upper fields of the table. With high partnership complexity and a fuzzy mix of formalization and informality, it veered between very specific solutions (in essence, a transfer of knowledge from universities to companies) and lofty ambitions (business opportunities, cutting-edge innovation, and regional development) that eventually came to disappoint some of the partners.

\subsection{Implications for partners and the organization of partnerships}

This proposition has implications for the establishment and governance of innovation partnerships. First, it underlines the importance of designing the organization of a partnership purposefully to its key objective and environment. It is time to bring this classic insight into innovation studies and public innovation policy from organizational contingency theory. A profound insight from Lawrence and Lorch (1967) is, for example, that the complexity and uncertainty of a task requires a matching appreciation of conflict in the organizational system and its coordination mechanisms. Accordingly, innovation partnerships should carefully consider their partnership composition and adopt control and coordination mechanisms depending on their goal(s).

If the purpose of public funding is incremental innovation, Table 3 suggests that an innovation partnership working towards this end should be of a limited size and hybridity and work with a relatively high degree of formalization. If a partnership focuses on radical innovation, that is, the development of completely new solutions, it must be of limited size and hybridity, not very formalized, but with trust among the partners in each other's resources (Bika and Kalantardis, 2019). If the partnership expands in size and hybridity, it will best support the transfer of existing technology and knowhow, in which case it should be relatively formalized, or innovation of a more noncommittal nature that will be stifled under heavy formalization.

\subsection{Practical implications for public funders}

Currently, the general trend in public funding schemes goes towards an increasing number of partners and complex goals for innovation partnerships. Supporting this trend, the idea that innovation alliances and partnerships should be ambidextrous and able to conduct both exploration and exploitation (Sun and Lo, 2014) has been thriving. However, our analysis calls for light and shade into such ambitions and for investigating more thoroughly how innovation partnerships are best organized for their particular purpose. Here, we might learn from other organizational studies. Dougherty's work on product innovation management is one such example (Dougherty, 2008). She argues that three types of 'unmanageables', namely, segmentalism, rigidity, and coercive control, stifle innovation in organizations. Yet, rather than loosening organizational structure, as has been the dominant recommendation, she advocates for carefully calibrating the formal structure to make it support rather than 
undermine innovation processes. Adler et al. (2009) present a similar point, emphasizing that ambidextrous organizations require structuring and systematizing, but with a keen eye for the tension between trust and profit pressures. Insights such as these may help develop requisite models for different kinds of innovation partnerships. Rather than adopting a one-size-fits-all approach, public funding should adjust the design and performance criteria for partnerships, depending on their innovation purpose.

This raises the question of whether public funding should support all types of innovation partnerships. Discussing the potential risk of crowding out private investments, Beck and colleagues investigate which types of innovation have the greatest requirement for public funding and find that the impact of public funding is higher in radical innovation than in incremental innovation. They argue that incremental innovation carried out in horizontal collaboration (e.g., across industry and university) makes the impact even poorer (Beck et al., 2016). In line with Beck et al., we conclude that publicly funded innovation partnerships should not strive for high partnership complexity, as this will tend to drive the partnerships towards tech/knowledge transfer (for which there are typically already several institutions in place) or towards non-committal serendipity (with the risk of no practical results).

\subsection{Limitations and implications for research}

Our study has limitations that should be considered. While our case study design allows for analytical generalization (Flyvbjerg, 1996), it cannot claim to have exhausted the phenomenon of mission drift. There might be other dynamics involved that we did not come across in the IFD framework but may be found in other frameworks.

In addition, while we covered different types of innovation across the nine cases (product, process, and social innovation), our most detailed study focuses on process innovation. There might be nuances that we have missed, which may be crucial in determining which types of innovation public funders should be involved in and how these are most appropriately organized. These limitations to our study naturally call for more research into the details of innovation partnerships, thus opening up the organizational black box of a model that is becoming increasingly popular.

\section{Conclusion}

The results of our empirical analyses and subsequent theorizing show that there is a risk that public funding, such as the IFD Grand Solutions scheme, is not optimally spent owing to unsolved tensions between goal expectations, partnership composition, and lack of appropriate formalization. In the current organizational framework, IFD is likely to support either technology transfer projects that could and should have been carried out by the parties themselves, or projects of an exploratory but vague nature. Thus, the following lessons can be drawn from our study.

- Public support should be targeted at the innovation purposes of societal interest that parties cannot or will not fund themselves. Subsequently, the organizational framework, namely, formal contracts, soft and hard coordination mechanisms, key performance indicators, time frames, and so forth should be designed to stimulate and direct this purpose.

- More exploratory and detailed research is required to inform organizational design, particularly regarding the appropriate time frame and partnership complexity for radical innovation partnerships. As the IFD cases show, the current time horizon of three to five years is not ideal for high-complexity partnerships, which must establish trust, secure sufficient learning, and move towards concrete results. They tend to solve time pressure by operating with fuzzy and non-committal innovation goals. 
- There is a requirement to find a good design in which the purpose of innovation is discerned from economic effects and short-term goals. Often, innovation goals are overshadowed by goals concerned with economic effects, which hinders a realistic and important clarification of innovation goals.

- Finally, evaluation criteria should be carefully considered to ensure that they match the type of partnership in question and its innovation purpose.

\section{References}

Adler, P.S., Benner, M., Brunner, D.J., MacDuffie, J.P., Osono, E., Staats, B.R., Takeuchi, H., Tushman, M. and Winter, S.G. (2009), "Perspectives on the productivity dilemma", Journal of Operations Management, Vol. 27 No. 2, pp.99-113.

Arnold, E. (2004), "Evaluating research and innovation policy: a systems world needs systems evaluations", Research Evaluation, Vol. 13 No. 1, pp.3-17.

Bammer, G. (2008), "Enhancing research collaborations: three key management challenges", Research Policy, Vol. 37 No. 5, pp.875-887.

Battilana, J., Besharov, M. and Mitzinnek, B. (2017), "On hybrids and hybrid organizing: a review and roadmap for future research", in Greenwood, R., Oliver, C., Lawrence, T.B., \& R.E. Meyer (Eds.), The SAGE Handbook of Organizational Institutionalism, 2nd ed., SAGE Publications, Thousand Oaks, CA, pp.128-162.

Beck, M., Lopes-Bento, C. and Schenker-Wicki, A. (2016), "Radical or incremental: where does R\&D policy hit?”, Research Policy, Vol. 45 No. 4, pp.869-883.

Belderbos, R., Carree, M. and Lokshin, B. (2004), "Cooperative R\&D and firm performance", Research Policy, Vol. 33 No. 10, pp.1477-1492.

Bendis, R. and Byler, E. (2009), "Creating a National Innovation Framework: building a public-private support system to encourage innovation", available at http://www.innovationamerica.us/images/stories/pdf/bendis_innovation.pdf (accessed 17 July 2020).

Benner, M. and Tushman, M.L. (2003), "Exploitation, exploration and process management: the productivity dilemma revisited", Academy of Management Review, Vol. 28 No. 2, pp.238-256.

Bika, Z. and Kalantardis, C. (2019), "Organizational-social-capital, time and international family SMEs: an empirical study from the East of England", European Management Review, Vol. 16 No. 3, pp.525-541.

Breznitz, D. and Zehavi, A. (2010), "The limits of capital: transcending the public financerprivate producer split in industrial R\&D”, Research Policy, Vol. 39 No. 2, pp.301-312.

Busom, I. and Fernández-Ribas, A. (2008), "The impact of firm participation in R\&D programmes on R\&D partnerships", Research Policy, Vol. 37 No. 2, pp.240-257.

Caldwell, N., Roehrich, J. and George, G. (2017), "Social value creation and relational coordination in public-private collaborations", Journal of Management Studies, Vol. 54 No. 6, pp.906-928.

Cassiman, B., Veugelers, R. and Arts, S. (2018), "Mind the gap: capturing value from basic research though combining mobile inventors and partnerships", Research Policy, Vol. 47 No. 9, pp.1811-1824.

Chai, S. and Shih, W. (2016), "Bridging science and technology through academic-industry partnerships", Research Policy, Vol. 45 No. 1, pp.148-158.

Chen, M. and Wang, M. (2008), "Social networks and a new venture's innovative capability: the role of trust within entrepreneurial teams", $R \& D$ Management, Vol. 38 No. 3, pp.253-264.

Coleman, J. (1988), "Social capital in the creation of human capital", American Journal of Sociology, Vol. 94, pp.95-120. 
Collins, C.J., Smith, K.G. (2006), "Knowledge exchange and combination: the role of human resource practices in the performance of high technology firms", Academy of Management Journal, Vol. 49 No. 3, pp.544-560.

Das, T.K. and Teng, B-S. (1996), "Between trust and control: developing confidence in partner cooperation in alliances", Academy of Management Review, Vol. 23 No. 3, pp.491-512.

Ebers, M. and Maurer, I. (2014), "Connections count: how relational embeddedness and relational empowerment foster absorptive capacity", Research Policy, Vol. 43 No. 2 , pp.318-332.

Ebrahim, E., Battilana, J. and Mair, J. (2014), "The governance of social enterprises: Mission drift and accountability challenges in hybrid organizations", Research in Organizational Behavior, Vol. 34, pp.81-100.

European Commission (2010), Europe 2020 Flagship Initiative Innovation Union, Bruxelles.

Flyvbjerg, B., (2006), "Five misunderstandings about case-study research", Qualitative Inquiry, Vol. 12 No. 2, pp.219-245.

Gilier, T., Kazakci, A.O. and Piat, G. (2012), "The generation of common purpose in innovation partnerships: a design perspective", European Journal of Innovation Management, Vol. 15 No. 3, pp.372-392.

Grimes, M., Williams, T., and Zhao, E. (2019), "Anchors aweigh: the sources, variety, and challenges of mission drift", Academy of Management Review, Vol. 44 No. 4, pp.819845.

Hagedoorn, J., Link, A.N. and Vonortas, N.S. (2000), "Research partnerships", Research Policy, Vol. 29 No. 4-5, pp.567-589.

Hertzfeld, H.R., Link, A.N. and Vonortas, N.S. (2006), "Intellectual property mechanisms in research partnerships", Research Policy, Vol. 35 No. 6, pp.825-838.

Häusler, J., Hohn, H-W. and Lutz, S. (1994), "Contingencies of innovative networks: a case study of successful interfirm R\&D collaboration”, Research Policy, Vol. 23 No. 19, pp.47-66.

Jaffe, Adam B. (1998), “Measurement issues”, Branscomb, L. \& Keller, J. (Ed.s), Investing in Innovation, The MIT Press, Cambridge MA, pp.64-84.

Kaiser, U. and J.M. Kuhn (2012) "Long-run effects of public-private research joint ventures: the case of the Danish Innovation Consortia support scheme", Research Policy, Vol. 41 No. 5, pp.913-927

Kollock, P. (1994), "The emergence of exchange structures: an experimental study of uncertainty, commitment, and trust", American Journal of Sociology, Vol. 100 No. 2, pp.313-345.

Kumar, R. and Nti, K.O. (1998), "Differential learning and interaction in alliance dynamics: a process and outcome discrepancy model”, Organization Science, Vol. 9 No. 3, pp.255433.

Langford, C., Hall, J., Josty, P., Matos, S., and Jacobson, A. (2006), "Indicators and outcomes of Canadian university research: proxies becoming goals?", Research Policy, Vol. 35 No. 10, pp.1586-1598

Larsson, R., Bengtsson, L., Henriksson, K. and Sparks, J. (1998), “The interorganizational learning dilemma: collective knowledge development in strategic alliances", Organization Science, Vol. 9 No. 3, pp.285-305.

Lawler, E. and Yoon, J. (1998), "Network structure and emotion in exchange relations", American Sociological Review, Vol. 63 No. 6, pp.871-894.

Lawrence, P.R. and Lorsch, J.W. (1967), Organization and Environment, Harvard Business School Press, Cambridge, MA.

Lokshin, B., Hagedoorn, J. and Letterie, W. (2011), “The bumpy road of technology 
partnerships: understanding causes and consequences of partnership mal-functioning", Research Policy, Vol. 40 No. 2, pp.297-308.

March, J.G. (1991), "Exploration and exploitation in organizational learning", Organization Science, Vol. 2 No. 1, pp.71-87.

Ministry of Higher Education and Science (2019), Innovation Fund Denmark - Report of the International Evaluation Panel 2019, Copenhagen.

Nooteboom, B. (1996), "Trust, opportunism and governance: a process and control model", Organization Studies, Vol. 17 No. 6, pp.985-1010.

Nooteboom, B. (1999), Inter-firm Alliances: Analysis and Design, Routledge, London.

Nooteboom, B. (2002), Trust: Forms, Foundations, Functions, Failures and Figures, Edward Elgar Publishing Limited, Cheltenham.

Quélin, B.V., Kivleniece, I. and Lazzarini, S. (2017), "Public-private collaboration, hybridity and social value: towards new theoretical perspectives", Journal of Management Studies, Vol. 54 No. 6, pp.763-792.

Perkman, M., McKelvey, M. and Phillips, N. (2018), "Protecting scientists from Gordon Gekko: how organizations use hybrid spaces to engage with multiple institutional logics", Organization Science, Vol. 30 No. 2, pp.298-318.

Ring, P.S. and Van de Ven, A. (1994), "Developmental processes of cooperative interorganizational relationships", Academy of Management Review, Vol. 19 No. 1, pp.90-118.

Schøtt, T. and Jensen, K.W. (2016), "Firms' innovation benefiting from networking and institutional support: a global analysis of national and firm effects", Research Policy, Vol. 45 No. 6, pp.1233-1246.

Sun, B. and Lo, Y. (2014), "Achieving alliance ambidexterity through managing paradoxes of cooperation”, European Journal of Innovation Management, Vol. 17 No. 2, pp.144165.

Ungureanu, P., Bertolotti, F. and Macri, D. (2018a), "Brokers or platforms? A longitudinal study of how hybrid interorganizational partnerships for regional innovation deal with VUCA environments", European Journal of Innovation Management, Vol. 21, No. 4, pp.636-667.

Ungureanu, P., Bertolotti, F., Mattarelli, E. and Bellesia, F. (2018b), "Making matters worse by trying to make them better? Exploring vicious circles of decision in hybrid partnerships", Organization Studies, Vol. 40 No. 9, pp.1331-1359.

Vikkelsø, S. (2015), "Core task and organizational reality”. Journal of Cultural Economy, Vol. 8 No. 4, pp.418-438.

Vedel, J. B. (2020), "Balancing conflicting goals in interorganizational collaborations in the pharmaceutical industry: a contractual dynamics view. European Management Review. https://doi.org/10.1111/emre.12429.

Voltan, A. and De Fuentes, C. (2016), "Managing multiple logics in partnerships for scaling social innovation”, European Journal of Innovation Management, Vol. 19 No. 4, pp.446-467.

Woolthuis, R., Hillebrand, B. and Nooteboom, B. (2005), "Trust, contract and relationship development", Organization Studies, Vol. 26 No. 6, pp.813-840.

Yin, R.K. (2003), Case Study Research: design and methods, $3^{\text {rd }}$ ed., Sage Publications, Thousand Oaks, CA.

Zucker, Lynn G. (1986), "Production of trust: institutional sources of economic structure, 1840-1920", Research in Organizational Behaviour, Vol. 8., pp.53-111. 


\section{TABLES 1-3 TO BE INSERTED IN THE PAPER}

Table 1. An overview of the studied partnerships in terms of scientific domain, type of innovation, persons interviewed, total funding and the types of partners

\begin{tabular}{|l|l|l|l|l|}
\hline SCIENTIFIC DOMAIN & $\begin{array}{l}\text { TYPE OF } \\
\text { INNOVATION }\end{array}$ & $\begin{array}{l}\text { PERSONS } \\
\text { INTERVIEWED }\end{array}$ & $\begin{array}{l}\text { TOTAL } \\
\text { FUNDING } \\
\text { (DKK) }\end{array}$ & $\begin{array}{l}\text { TYPES OF PARTNERS } \\
\text { INVOLVED }\end{array}$ \\
\hline $\begin{array}{l}\text { Food, medicine, veterinary } \\
\text { science }\end{array}$ & Product & 2 & $>75 \mathrm{M}$ & $\begin{array}{l}3 \text { hospitals, } 5 \text { universities, } \\
5 \text { companies }\end{array}$ \\
\hline $\begin{array}{l}\text { Environment, chemistry, } \\
\text { computer science }\end{array}$ & Product & 1 & $>25 \mathrm{M}$ & 1 university, 3 companies \\
\hline Social science, textile design & $\begin{array}{l}\text { Service and } \\
\text { product }\end{array}$ & 1 & $>5 \mathrm{M}$ & $\begin{array}{l}3 \text { universities, } 1 \text { college, } \\
\text { companies, } 1 \text { NGO, } \\
1 \text { municipality }\end{array}$ \\
\hline Engineering, robotics & Product & 2 & $>25 \mathrm{M}$ & $\begin{array}{l}3 \text { universities, } 1 \text { company, } 1 \\
\text { startup }\end{array}$ \\
\hline Food, farming & Process & 1 & $>25 \mathrm{M}$ & $\begin{array}{l}2 \text { universities, } \\
1 \text { technological institute, } \\
7 \text { companies/farms }\end{array}$ \\
\hline Energy & Process & 1 & $>25 \mathrm{M}$ & 3 universities, 2 companies \\
\hline Engineering, sustainability & Process & 1 & $>100 \mathrm{M}$ & $\begin{array}{l}3 \text { universities, } \\
2 \text { technological institutes, } \\
1 \text { NGO, 14 companies }\end{array}$ \\
\hline $\begin{array}{l}\text { Computer science, social } \\
\text { science }\end{array}$ & Product & 1 & $>25 \mathrm{M}$ & 2 universities, 1 company \\
\hline $\begin{array}{l}\text { Biotech, computer science, } \\
\text { engineering }\end{array}$ & Process & 15 & $>100 \mathrm{M}$ & $\begin{array}{l}2 \text { universities, } 1 \text { investment } \\
\text { firm, } 5 \text { companies, } \\
\text { several startups }\end{array}$ \\
\hline interviews with IFD officers & 27 & & \\
\hline
\end{tabular}


Table 2. Data display showing the coding structure and examples from coded interviews (anonymized, grammatically corrected and partly translated)

\begin{tabular}{|c|c|c|}
\hline $\begin{array}{l}\text { TYPE OF } \\
\text { CHALLENGE }\end{array}$ & $\begin{array}{l}\text { THE ROLE OF PARTNERSHIP COMPOSITION } \\
\text { IN HANDLING THE CHALLENGE }\end{array}$ & $\begin{array}{l}\text { THE ROLE OF FORMALIZATION IN HANDLING } \\
\text { THE CHALLENGE }\end{array}$ \\
\hline TRUST & $\begin{array}{l}\text { "I think there is a secret in saying that some of the } \\
\text { companies in a way is in the same family. I mean } \\
\text { Company X is the same group. They partly owned } \\
\text { Company Y. And then we have Company Z which is now } \\
\text { a [foreign] company [...] They are facing the same kind } \\
\text { of quite serious problems in making the next step in their } \\
\text { production. And even they're big, they find a way to } \\
\text { cooperate. And the key word, I think, is confidence. } \\
\text { We've reached a level of confidence where they are } \\
\text { open...sitting around this table open about what's our } \\
\text { main problem". }\end{array}$ & $\begin{array}{l}\text { "[A] thing that I see being different from most of our other } \\
\text { collaboration projects is that the whole debate around IP } \\
\text { and confidentiality is dealt with upfront. When we normally } \\
\text { go to a university for doing some collaboration, we can } \\
\text { spend a lot of time talking IP [...]. Actually, I'm not sure } \\
\text { why they want it. I think they believe they someday can sell } \\
\text { the patent and maybe make some money. But if you look at } \\
\text { the history of the universities, that rarely ever happens. [...] } \\
\text { To me, it's a waste of time and it's standing in the way of } \\
\text { doing collaboration and research together". }\end{array}$ \\
\hline GOAL-SETTING & $\begin{array}{l}\text { "There was sort of missing a shared need...but it has } \\
\text { actually emerged through a shared dependency on each } \\
\text { other, because we have created a much closer relation. } \\
\text { And we have come to see that there is actually some } \\
\text { knowledge on the shelves that we didn't know about and } \\
\text { that have proven useful in the companies from day one. } \\
\text { And then we have extended the collaboration, because } \\
\text { also the universities realized that here (in the } \\
\text { companies) is an opportunity to use a big scale research } \\
\text { apparatus". }\end{array}$ & $\begin{array}{l}\text { "I wonder whether they've set very clear expectations up } \\
\text { front in the EO collaboration in terms of the spinouts. From } \\
\text { the companies' perspective it's very nice to get free, } \\
\text { dedicated access to the universities and to PhD students that } \\
\text { can do feasibility studies on new technology. But, if I'm } \\
\text { tough, it's a little bit free riding [...]. Somebody has to pay } \\
\text { for the lunch and they're just getting some nice information } \\
\text { out of it. Whereas if you need to pay yourself, then normally } \\
\text { in a big organization you need to make a business case [...] } \\
\text { to make sure that it's not nice to have but need to have". }\end{array}$ \\
\hline LEARNING & $\begin{array}{l}\text { "I think that you need this group of what you call } \\
\text { resourceful companies, and you can feel the members } \\
\text { who is coming to the team are committed. If you don't } \\
\text { get this commitment, it's easy, it would be easy for me to } \\
\text { come every quarter and say have you got anything I can } \\
\text { use now. I go home wait for three months. You need a } \\
\text { coalition of people who all want to bring something to } \\
\text { the table". }\end{array}$ & $\begin{array}{l}\text { "I would not convince my colleagues [to sign the contract] } \\
\text { by power. I convinced them by circulating the idea that they } \\
\text { were simply participating. It took time. To begin with, these } \\
\text { good guys said, ah, what about our confidentiality? And } \\
\text { some of them said, okay, they would not participate. And } \\
\text { "okay, fine", then we went a little bit away from some of the } \\
\text { projects there. But after two, three years and more and more } \\
\text { learning about it and working together, they accepted it. It's } \\
\text { a... very important key to this". }\end{array}$ \\
\hline COORDINATION & $\begin{array}{l}\text { "I don't think there have been many problems. So, the } \\
\text { big companies will for natural reasons have tried this } \\
\text { before. And the small companies that are involved, the } \\
\text { startups, they have staff that are pretty much like } \\
\text { academic staff. So many of them have come from } \\
\text { university of some kind and have tried research projects } \\
\text { and so on. [...] It seems natural to them. Whereas the } \\
\text { companies that I have had problems with have staff and } \\
\text { directors and so on that have never been to university". }\end{array}$ & $\begin{array}{l}\text { "Our project execution... we have a way at looking at it: the } \\
\text { companies...can be exploitative and strict in the way they } \\
\text { execute projects. Universities are very explorative. They like } \\
\text { to be up here (in the explorative field). Companies are very } \\
\text { strict: they want a project plan. And one of my big jobs in } \\
\text { EO is actually to, when we start projects, to tell } \\
\text { companies... they often have a short-term idea...to relax so } \\
\text { the universities can get space to be explorative, to think out } \\
\text { of the box. But ... in university settings time is no issue and } \\
\text { they can be exploratory forever. So... when we have been } \\
\text { explorative enough, I kind of shift". }\end{array}$ \\
\hline
\end{tabular}


Table 3. Depending on partnership complexity and degree of formalization, the mission of a partnership is likely to drift towards one of four types of innovation

\begin{tabular}{|c|c|c|}
\hline & $\begin{array}{c}\text { High degree of } \\
\text { formalization } \\
\text { (exploitation) }\end{array}$ & $\begin{array}{c}\text { Low degree of } \\
\text { formalization } \\
\text { (exploration) }\end{array}$ \\
\hline $\begin{array}{c}\text { Low partner } \\
\text { complexity }\end{array}$ & Incremental innovation & Radical innovation \\
\hline $\begin{array}{c}\text { High partner } \\
\text { complexity }\end{array}$ & $\begin{array}{c}\text { Technology/knowledge } \\
\text { transfer }\end{array}$ & $\begin{array}{c}\text { Non-committal } \\
\text { serendipity }\end{array}$ \\
\hline
\end{tabular}

